DOI: $10.20473 / \mathrm{mkh} . v 32 i 2.2021 .70-78$

\title{
Diagnosa dan Observasi Terapi Infestasi Ektoparasit Notoedres cati Penyebab Penyakit Scabiosis Pada Kucing Peliharaan
}

\author{
Diagnosis and Observation Therapy of Ectoparasite Infestation Notoedres \\ cati Causes of Scabiosis in Domestic Cat
}

\author{
Aditya Yudhana ${ }^{*}$, Ratih Novita Praja ${ }^{2}$, Arum Pratiwi ${ }^{3}$, Nuril Islamiyah ${ }^{3}$ \\ 1Divisi Parasitologi Veteriner, Fakultas Kedokteran Hewan, Universitas Airlangga, \\ 2Divisi Mikrobiologi Veteriner, Fakultas Kedokteran Hewan, Universitas Airlangga, \\ 3 Pendidikan Profesi Dokter Hewan, Fakultas Kedokteran Hewan, Universitas \\ Airlangga, \\ *Jalan Wijaya Kusuma 113, Kampus Banyuwangi, Jawa Timur, Indonesia, \\ Telp. (0333) 417788, Fax (0333) 428890 \\ *E-mail : adityayudhana@fkh.unair.ac.id
}

\begin{abstract}
ABSTRAK
Scabiosis merupakan penyakit parasitik yang paling sering terjadi pada kucing peliharaan. Penyebab scabiosis pada kucing paling dominan adalah ektoparasit tungau Notoedres cati. Jumlah kasus scabiosis pada kucing peliharaan di Indonesia masih terbilang tinggi sehingga diperlukan pendekatan diagnosa yang tepat dan pengendalian yang komprehensif. Laporan kasus ini bertujuan untuk menginvestigasi aspek diagnosa dan terapi kasus scabiosis pada kucing peliharaan sekaligus laporan pertama di dari wilayah Banyuwangi, Jawa Timur. Berdasarkan pemeriksaan gejala klinis dan skin scraping dapat dikonfirmasi bahwa diagnosa untuk pasien kucing adalah positif scabiosis akibat infestasi tungau Notoedres cati. Tindakan terapi yang dilakukan adalah dengan obat injeksi ivermektin yang dikombinasikan dengan terapi topical menggunakan sulfur sebagai anti parasitik. Hasil kombinasi terapi yang diperoleh dengan menggunakan injeksi ivermectin dan sulfur secara topikal, dapat dikonfirmasi proses perkembangan yang signifikan, ditandai dengan adanya perbaikan lesi kulit atau terjadi proses keratolisis pada bagian yang mengalami lesi khas scabiosis yaitu hiperkeratosis. Laporan kasus ini dapat bermanfaat bagi para dokter hewan praktisi dalam menentukan diagnosa dan terapi scabiosis pada kucing. Selain itu, informasi ilmiah pada laporan kasus juga berfungsi sebagai edukasi kepada para pemilik hewan
\end{abstract}


peliharaan terkait dengan pentingnya manajemen perawatan dan pencegahan penyakit yang berpotensi zoonosis.

Kata Kunci: Kucing, Notoedres cati, Scabies, Scabiosis

\begin{abstract}
Scabiosis is a skin parasitic disease which frequently occurs in pet cats and known as feline scabiosis. The causative agent of feline scabiosis was dominated by Notoedrescati as parasitic mite. The number of feline scabiosis in Indonesia remains in high number, therefore, proper diagnostic approach and comprehensive disease control is necessary. Present case report aims to investigate the diagnostic approach and treatment regarding feline scabiosis in a pet cat. Moreover, present study also becomes the first report in Banyuwangi City, East Java Province. Based on physical examination and skin scraping method, a pet cat patient was accurately diagnose with Notoedrescati mite infestation. The treatment method was performed using combination of ivermectin as injection and sulphur shampoo as antiparasitic topical treatment. The results shows significant progress with a sign of decreasing crust and hyperkeratosis lesion which known as specific clinical sign for scabiosis in mammals. Present case report also have significant impact for veterinary practitioner regarding diagnostic and treatment approach against feline scabiosis patient. Moreover, scientific information in present case report could be use as educational purposes to pet owners regarding the importance of their pet health management and prevention measures in parasitic disease with zoonotic potential.
\end{abstract}

Keyword: Cat, Notoedres cati, Scabies, Scabiosis

\section{PENDAHULUAN}

Kucing pada umumnya lebih dominan dijadikan sebagai hewan peliharaan di Indonesia karena karakternya dan corak warna pada rambut. Dewasa ini, banyak ras kucing yang sudah berhasil dilakukan perkawinan secara alami di Indonesia seperti kucing ras persian, mainecoon, sphynx dan bengal. Manajemen kesehatan kucing merupakan salah satu informasi penting yang harus diperhatikan oleh pemilik (Amir et al., 2020). Penyakit kulit yang disebabkan oleh ektoparasit merupakan masalah kesehatan yang umum ditemukan dalam kasus klinik dengan pasien hewan domestik yang dimanfaatkan sebagai peliharaan. Kucing merupakan hewan peliharaan domestik yang rentan terhadap paparan agen infeksius parasit dimana kasusnya didominasi oleh infestasi ektoparasit tungau. Penyakit kulit akibat infestasi tungau mikroskopik yang kita kenal dengan 
istilah scabies atau scabiosis ini merupakan salah satu penyakit kulit yang mendominasi pada kucing, baik yang dipelihara maupun liar (Senthil et al., 2008). Penyakit ini sangat mudah menular dari satu kucing ke kucing yang lain sehingga sangat merugikan dan dapat berakibat fatal apabila tidak dilakukan terapi yang tepat indikasi. Manifestasi klinis dari tungau dapat menyebabkan penebalan jaringan pada kulit dan menimbulkan kondisi patologis berupa timbulnya krusta yang terlihat seperti kerak berwarna kuning sampai abu-abu (Scott et al., 2001).

$$
\text { Ektoparasit tungau yang }
$$
menjadi penyebab utama masalah kesehatan kulit pada kucing adalah Notoedres cati. Tungau spesies Notoedres cati selain menyebabkan penyakit scabiosis pada kucing, berpotensi juga menyebabkan masalah kulit pada manusia. Gejala klinis berupa dermatitis akibat dari infestasi tungau Notoedres cati pernah dilaporkan pada manusia sehingga ektoparasit tersebut juga mempunyai potensi zoonosis (Sivajothi et al., 2014). Infestasi ektoparasit pada tungau juga dapat memicu terjadinya infeksi sekunder dari agen infeksius lain seperti bakteri dan menyebabkan penyakit pada kulit menjadi lebih parah. Kasus scabiosis pada kucing yang disertai infeksi sekunder umumnya lebih sulit dilakukan terapi dan perlu diagnosa komprehensif dari dokter hewan praktisi yang menangani (Reddy et al., 2014).
Scabiosis juga menimbulkan sensasi gatal pada kucing yang umumnya akan terlihat selalu menggaruk pada bagian teling. Bagian telinga yang sering tergaruk tersebut bisa menjadi luka terbuka akibat gesekan dengan cakar dan berlanjut menjadi reaksi peradangan yang disertai peningkatan produksi kotoran telinga atau bahkan eksudat purulent. Kondisi klinis tersebut dikenal dengan otitis atau radang pada bagian telinga kucing, yang dipicu oleh penyebab utamanya adalah infestasi tungau Notoedres cati (Ahaduzzamanet al., 2014). Angka kejadian kasus yang tinggi disertai dengan potensi zoonosis menyebabkan infestasi tungau Notoedres cati pada kucing masih terbilang sulit dan penuh tantangan baik dari aspek medik veteriner maupun riset terkait efektivitas terapi (Itoh et al., 2004). Laporan kasus ini bertujuan untuk menginvestigasi terjadinya infestasi tungau Notoedres cati pada pasien kucing peliharaan, sekaligus menjadi laporan pertama di wilayah Kabupaten Banyuwangi, Jawa Timur. Hasil dari laporan kasus ini diharapkan dapat menambah data ilmiah terkait kasus scabiosis yang sering terjadi pada kucing di Indonesia, sehingga dapat dilakukan rekomendasi pengobatan serta pengendalian penyakit secara tepat dan akurat. 


\section{MATERI DAN METODE}

\section{Riwayat Kasus}

Seekor kucing ras persian berumur 6 bulan diperiksakan ke klinik hewan pendidikan Prodi Kedokteran Hewan Universitas Airlangga Program Studi di Luar Kampus Utama (PSDKU) Banyuwangi. Kondisi kucing pada saat dilakukan observasi klinis ditemukan adanya kondisi tremor pada bagian leher dan seluruh ekstremitas, dermatitis kronis, krusta pada bagian ujung telinga (Gambar 1). Bagian ekor kucing terdeteksi menunjukkan gejala klinis paling parah yaitu alopecia, pruritus dan hiperkeratosis yang disertai dengan reaksi peradangan kronis dari pangkal hingga ujung ekor (Gambar 2). Pasien kucing sempat dilakukan terapi berupa grooming treatment secara berkala hingga satu bulan namun ternyata tidak menunjukkan hasil kesembuhan yang signifikan.

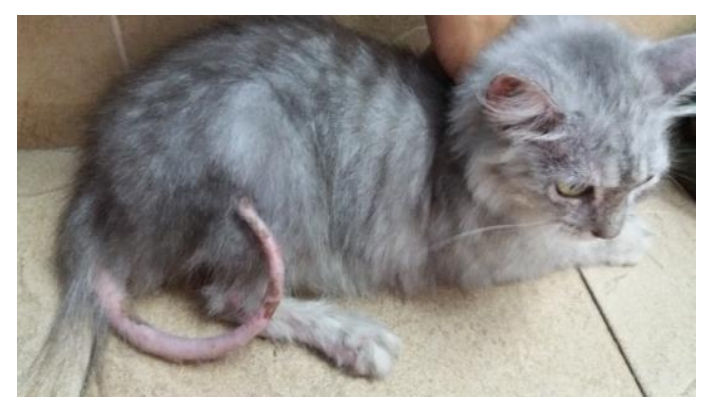

Gambar 1. Gejala pruritus dan alopecia pada kucing ras persian penderita scabiosis

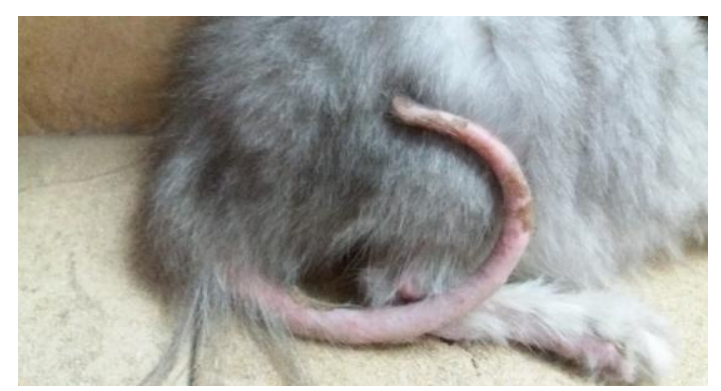

Gambar 2. Alopecia dan hiperkeratosis pada pangkal hingga jung ekor kucing

Pemeriksaan klinis scabiosis dapat dilihat dari aktivitas anggota gerak berupa intensitas menggaruk dan cara menggaruk pada bagian yang terindikasi muncul gejala klinis. Refleks pinnal-pedal positif yaitu reaksi yang terlihat pada saat hewan digaruk di belakang telinga, dan menirukan gerakan menggaruk dengan kaki belakang di sisi tubuh yang sama, dapat terlihat pada kucing. Nilai potensial dari refleks awal pinnal-pedal dapat digunakan sebagai indikasi untuk diagnosa kasus scabiosis pada kucing. Reflek tersebut dapat dinilai dengan menggosokkan ujung satu ear flap ke pangkal telinga dengan kuat selama 5 detik dan kategori positif jika kaki belakang merespon dengan melakukan gerakan menggaruk (Bettenay et al., 2001).

\section{PemeriksaanLaboratorium}

Respon menggaruk yang terjadi pada kucing dapat menyebabkan goresan luka pada kulit sehingga kulit terlihat menjadi kemerahan dan terjadi reaksi peradangan. Pemeriksaan kerokan kulit (scraping) dilakukan pada area yang mengalami kondisi patologis 
berupa krusta, alopecia dan pruritus untuk menunjang diagnosa scabiosis sekaligus identifikasi tungau yang ditemukan. Runtuhan krusta hasil scraping selanjutnya dilakukan clearing dengan menggunakan larutan $\mathrm{KOH}$ $10 \%$ dan diperiksa dengan mikroskop (Soulsby, 1968). Tungau Notoedres cati dilakukan identifikasi menurut kriteria dari Walker (1994). Tungau Notoedres cati mempunyai ukuran yang lebih kecil dan bulat jika dibandingkan dengan Sarcoptes scabiei, serta bagian anus terletak pada bagian dorsal tubuh (Gambar 3). Projecting scale tidak terlihat pada Notoedres cati dan pada bagian

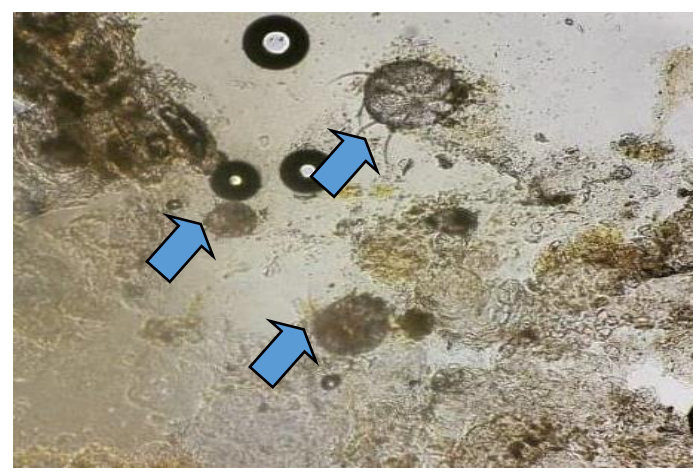

Gambar 3. Tungau Notoedres cati (tanda panah) yang ditemukan pada hasil pemeriksaan skin scrapping (perbesaran mikroskop 400X)

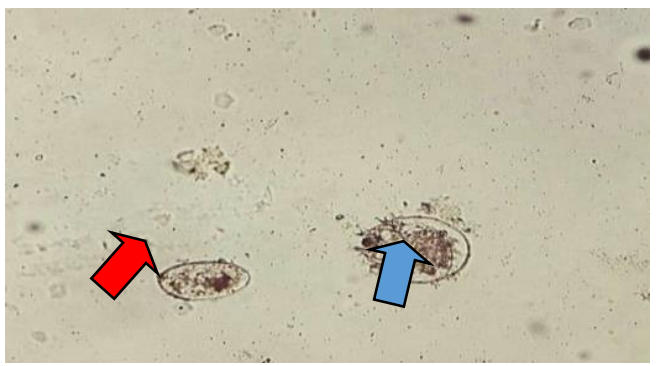

Gambar 4. Morfologi tungau Notoedres cati dewasa (panah biru) dan telur (panah merah) pada pemeriksaan mikroskop perbesaran 400x mid-dorsal, organ striae terbagi menjadi beberapa bagian yang membentuk pola menyerupai scale (Gambar 4).

\section{HASIL}

\section{Diagnosa dan Terapi}

Berdasarkan pemeriksaan gejala klinis dan skin scraping dapat dikonfirmasi bahwa diagnosa untuk pasien kucing adalah positif scabiosis akibat infestasi tungau Notoedres cati. Tindakan terapi yang dilakukan adalah dengan obat injeksi ivermectin (Intermectin ${ }^{\circledR}$, PT. Tekad Mandiri Citra, Bandung, Indonesia) dengan dosis yang diberikan adalah $0,2 \mathrm{mg} / \mathrm{kg}$ BB dengan dua kali pemberian pada interval 7 hari selama 1 bulan melalui rute sub kutan. Pemberian terapi juga dikombinasi dengan tindakan suportif berupa grooming anti ektoparasit berbahan utama sulfur setiap minggu serta pemberian vitamin. Tidak ditemukan adanya reaksi efek samping yang muncul pada saat proses terapi. Pada hari ke-7, gejala pruritus sudah mulai berkurang dan terlihat signifikansi terapi muncul setelah hari ke-14. Dua minggu pasca terapi, skin scraping kembali dilakukan dan hasilnya adalah negatif atau tidak ditemukan adanya infestasi ektoparasit tungau.

\section{PEMBAHASAN}

Notoedres cati merupakan tungau yang sangat menular pada berbagai jenis ras kucing (Scott et al., 2001). 
Ektoparasit ini sering ditemukan menginfestasi kucing namun tidak menutup kemungkinan bisa terjadi penularan pada anjing, tikus, kelinci dan bahkan manusia yang menimbulkan gejala dermatitis (Foley, 1991). Manajemen terapi scabiosis pada kucing tergantung dari perkembangan penyakit. Skin scraping merupakan metode diagnosa yang penting dalam menentukan evaluasi terapi yang telah dilakukan maupun hubungan faktor risiko yang berpengaruh terhadap proses kesembuhan penyakit. Gejala klinis yang diobservasi pada laporan kasus ini sejalan dengan laporan kasus sebelumnya (Itoh et al., 2004) yaitu berupa pruritus, alopecia dan timbulnya krusta pada kulit penderita. Pada laporan kasus ini, beda tingkat keparahan gejala klinis juga terdeteksi dimana pada umumnya scabiosis muncul dibagian telinga, namun ternyata pada pasien kucing yang terlaporkan terjadi pada bagian ekor. Hal tersebut bisa dikarenakan terapi yang belum tuntas atau kurang tepat dilakukan oleh pemilik sebelum diperiksakan ke klinik hewan. Ekspresi menggaruk dan rambut rontok pada beberapa bagian merupakan informasi yang mengarah pada infestasi tungau Notoedres cati pada kucing (Foil, 2003). Scraping yang dilakukan pada bagian lesi menunjukkan Notoedres cati dalam stadium dewasa dan telur yang menunjukkan pasien kucing dalam laporan kasus ini sudah terinfestasi tungau dalam kondisi kronis.
Notoedres cati merupakan tungau mikroskopik berukuran 150 - $220 \mu \mathrm{m}$, yang infestasinya ditemukan pada kucing dari berbagai usia. Pada kasus kronis, lesi yang timbul pada bagian kepala, telinga, dan leher yang awalnya ringan dapat berubah menjadi infestasi berat dan mematikan apabila tidak dilakukan terapi. Lesi pada umumnya ditemukan pada bagian perut, dada, kaki, telinga dan siku. Semakin jarang terdapat rambut maka tungau semakin berkembang dengan cepat. Apabila infestasi tungau menyebar ke seluruh tubuh, hewan akan mengalami gejala gatal yang parah, peradangan pada kulit dan bahkan terbentuk kerak yang berujung pada hiperkeratosis (Sivajothi et al., 2015).

Tungau betina mampu membuat terowongan dalam kulit dan meletakkan telur sepanjang terowongan yang dibentuk. Telur akan menetas dalam 3-8 hari menjadi stadium larva yang memiliki 3 pasang kaki. Larva selanjutnya berkembang menjadi nimfa yang memiliki 4 pasang kaki. Nimfa kemudian berganti kulit dan menjadi dewasa dengan ukuran tubuh yang lebih besar. Tungau dewasa setelah matang secara reproduksi akan melakukan kopulasi dan prosesnya berlanjut sampai betina menghasilkan telur. Seluruh siklus hidup tungau tersebut membutuhkan waktu antara 23 minggu (Diwakar, 2017). Notoedres cati merupakan tungau dari Famili Sacoptidae sehingga secara morfologi sangat mirip dengan Sarcoptes scabiei. 
Kunci dalam menentukan morfologi secara spesifik adalah Notoedres cati mempunyai ukuran yang lebih kecil dan bentukan tubuh yang lebih bulat jika dibandingkan dengan Sarcoptes scabiei. Bagian anus Notoedres cati terletak pada bagian dorsal tubuh dan tidak mempunyai bentukan projecting scale. Pada bagian mid-dorsal, organ striae terbagi menjadi beberapa bagian yang membentuk pola menyerupai scale (Walker, 1994).

Ivermectin merupakan kandungan obat yang analog dengan avermektin, dimana termasuk dalam kelompok senyawa lakton makro siklik, yang merupakan produk biologis dari jamur tanah Streptomyces avermilitis. Sampai saat ini diketahui bahwa bahan tersebut mempunyai efektivitas terhadap infestasi ektoparasit dan infeksi parasit gastro intestinal (Muniz et al., 1995; Couvillin, 1997). Mekanisme kerja ivermectin adalah dengan melepaskan dan mengikat a sebagai reseptor glutamate gated chloride channels (GluCl) pada sinapsis saraf (Wolstenholme, 2011) yang mampu menghambat proses fekunditas dan motilitas dari parasit (Yates et al., 2003). Ivermectin juga mempunyai mekanisme aksi pada neurotransmiter GABA sehingga mampu membuat blokir stimulasi inter neuronal pada bagian neuron motorik rangsang, sehingga menyebabkan kelumpuhan pada parasit yang terpapar obat tersebut (Sivajothi et al., 2015).
Pasien kucing pada kasus ini juga diberikan terapi suportif dengan cara grooming setiap minggu menggunakan shampoo anti ektoparasit yang memiliki kandungan sulfur. Sulfur mempunyai sifat kimia mudah mengalami sublimasi, dan ketika terjadi proses menyublim maka sulfur akan berikatan dengan ion hidrogen dan membentuk hidrogen sulfida. Hidrogen sulfide tersebut bersifat racun terhadap organisme. Apabila ektoparasit kontak dengan sulfur melalui rute per oral maka akan terbentuk substansi polythionic acid yang bersifat racun bagi ektoparasit tersebut (Senthil et al., 2008). Sulfur juga terbukti efektif untuk eliminasi tungau pada kulit dikarenakan mempunyai sifat panas. Terapi penunjang menggunakan sulfur sangat efektif jika infestasi tungau belum merusak kelapisan stratum korneum bagian dalam. Sulfur dapat membantu proses shedding dari kulit sebagai dampak proses pematangan sel-sel keratin pada stratum korneum yang menyebabkan kulit mengelupas. Reaksi tersebut sangat membantu dalam proses eliminasi ektoparasit tungau yang bersembunyi dalam terowongan di bagian epidermis penderita (Ilman et al.,2017).

Berdasarkan hasil kombinasi terapi yang diperoleh dengan menggunakan injeksi ivermectin dan sulfur secara topikal, dapat dikonfirmasi proses perkembangan yang signifikan, ditandai dengan adanya perbaikan lesi kulit atau terjadi 
proses keratolisis pada bagian yang mengalami lesi hiperkeratosis. Terapi pada hewan kasus menunjukkan hasil signifikan pada hari ke-7, terlihat gejala pruritus mulai berkurang dan nafsu makan mulai meningkat. Satu minggu pasca terapi, reaksi inflamasi dan alopecia pada bagian ekor mulai membaik serta krusta yang timbul pada kedua ekstremitas sudah mulai menipis. Bagian yang mengalami lesi alopecia juga mulai timbul rambut halus yang menandakan proses kesembuhan pada bagian kulit yang mengalami lesi scabiosis.

\section{KESIMPULAN}

Laporan kasus ini mengkonfirmasi kejadian infestasi tungau Notoedres cati pada pasien kucing peliharaan di wilayah Kabupaten Banyuwangi, Jawa Timur. Hasil yang diperoleh dari laporan kasus ini dapat bermanfaat bagi para dokter hewan praktisi dalam menentukan diagnosa dan terapi scabiosis pada kucing. Selain itu, informasi ilmiah pada laporan kasus juga berfungsi sebagai edukasi kepada para pemilik hewan peliharaan terkait dengan pentingnya manajemen perawatan dan pencegahan penyakit yang berpotensi zoonosis.

\section{UCAPAN TERIMA KASIH}

kasih kepada kolega dokter hewan yang tergabung dalam PDHI Jatim IV dan Parasitina selaku asisten laboratorium parasitologi yang telah membantu penulis dalam proses pemeriksaan pasien dan menyelesaikan laporan kasus ini.

\section{DAFTAR PUSTAKA}

Ahaduzzaman, M. 2014. Ear mite (Otodectescynotis) induced otitis externa and complicated by staphylococci infection in a Persian cat. J. Adv. Parasitol,2(2): $21-23$.

Amir, K.L., G.M.K. Erawan, P.G.YArjentinia. 2020. Case Report: Ivermectin and Sulfur Treatment For Scabiosis in Persian Cat. Indones. Med.Veterinus, 9(1): 89-98.

Bettenay, S.V., R.S. Mueller,M. Shipstone. 2001. Value of the pinnal-pedal reflex in the diagnosis of canine scabies. Vet.Rec. 148(20):621-623.

Couvillin, C, L.M.W. Pole,C.Sefker,M.B. Logam. 1997. Eficacy of doramectin for treatment of experimentally induced infection gastointersinal nematodes in calves. Am. J. Vet. Res. 58(3):282285.

Diwakar, R.P. 2017. Canine Scabies: A Zoonotic Ectoparasitic Skin Disease.

Int.J.Curr.Microbiol.App.Sci,6(4): 1361-1365. 
Foil, C.S. 2003. BSAVA manual of small animal dermatology. Edt. Foster,A.P. and Foil,C.S. IIndedn. BSAVA, Gloucestor, UK.

Foley, R.H. 1991. A notoedric mange epizootic in an island's cat population. Feline Prac, 19: 8-10.

Ilman, Z.A., S. Ida, A. Wiji,R.S Ika. 2017. Perbandinganefektivitassabun sulfur $\quad 10 \%$ dengansalep2-4 sebagaipengobatantunggal dan kombinasi pada penyakitskabies. Journal ofAgromedicine and Medical Sciences.3(3): 1-5.

Itoh, N., N. Muraoka, M. Aoki, T. Itagaki.2004. Treatment of Notoedric catiinfestation in cats with Selamectin. Vet. Res, 154(13): 409.

Muniz, R.A.,F. Hernandez,O. Lombardero, R.C Leite,J. Moreno,J.Errecalde, L.C.B Gonacalves. 1995. Effecicay of injection doramectin agains natura Boophylusmicroplus infestation in cattle. An.J. Res, 56(4): 460-463.

Reddy, B.S., K.N. Kumari, S. Sivajothi. 2014. Thyroxin levels and Haematological changes in dogs with Sarcoptic mange. J. Adv. Parasitol, 1(2): 27-29.

Scott, D.W., W.H. Miller, C.E. Griffin, C.E. 2001. Parasitic skin diseases. Muller and Kirk's small animal dermatology. (6th.Edn.), Philadelphia, W. B. Saunders Co., pp: 483- 484.
Senthil, K., P. Selvaraj,S. Vairamuthu, S.R. Srinivasan, and D. Kathiresan. 2008. Ivermectin therapy in the management of notoedric mange in cats. Tamilnadu J. Vet.Ani. Sci,4(6): 240-241.

Sivajothi, S., B.S. Reddy,V.C. Rayulu,C. Sreedevi. 2014. Notoedrescatiin cats and its management. J. Parasitol. Dis. DOI:10.1007/s12639-0130357-7.

Sivajothi, S., B.S. Reddy, R. Venkatasivakumar. 2015. Chronic dermatitis complicated with otitis due to Notoedrescatiin a Persian cat. J. Adv. Parasitology, 2(1): 1922.

Soulsby, E.J.L. 1968. Mites. In Helminths Arthropods and Protozoa of Domesticated Animals, Braillire, Tindall and Cassell, London, pp: 743

Walker, A. 1994. The Arthropods of human and domestic animal. Chapman and Hall, London. pp: 7-8.

Wolstenholme, A.J. 2011. Ion channels and receptor as targets for the control of parasitic nematodes.Int J Parasitol Drugs Drug Resist(1): 2-13.

Yates, D.M., V. Portillo, A.J. Wolstenholme. 2003. The avermectin receptors of Haemonchuscontortus and Caenorhabditis elegans. Int.Journal Parasitol,33(11):1183-1193. 